\title{
Pre-school teachers' knowledge and needs related to noticing gifted children and the enrichment model
}

\author{
Esra Dereli* \\ Pre-school Education, Faculty Of Education, Eskisehir Osmangazi University, Eskisehir \\ ORCID: 0000-0002-1726-3144
}

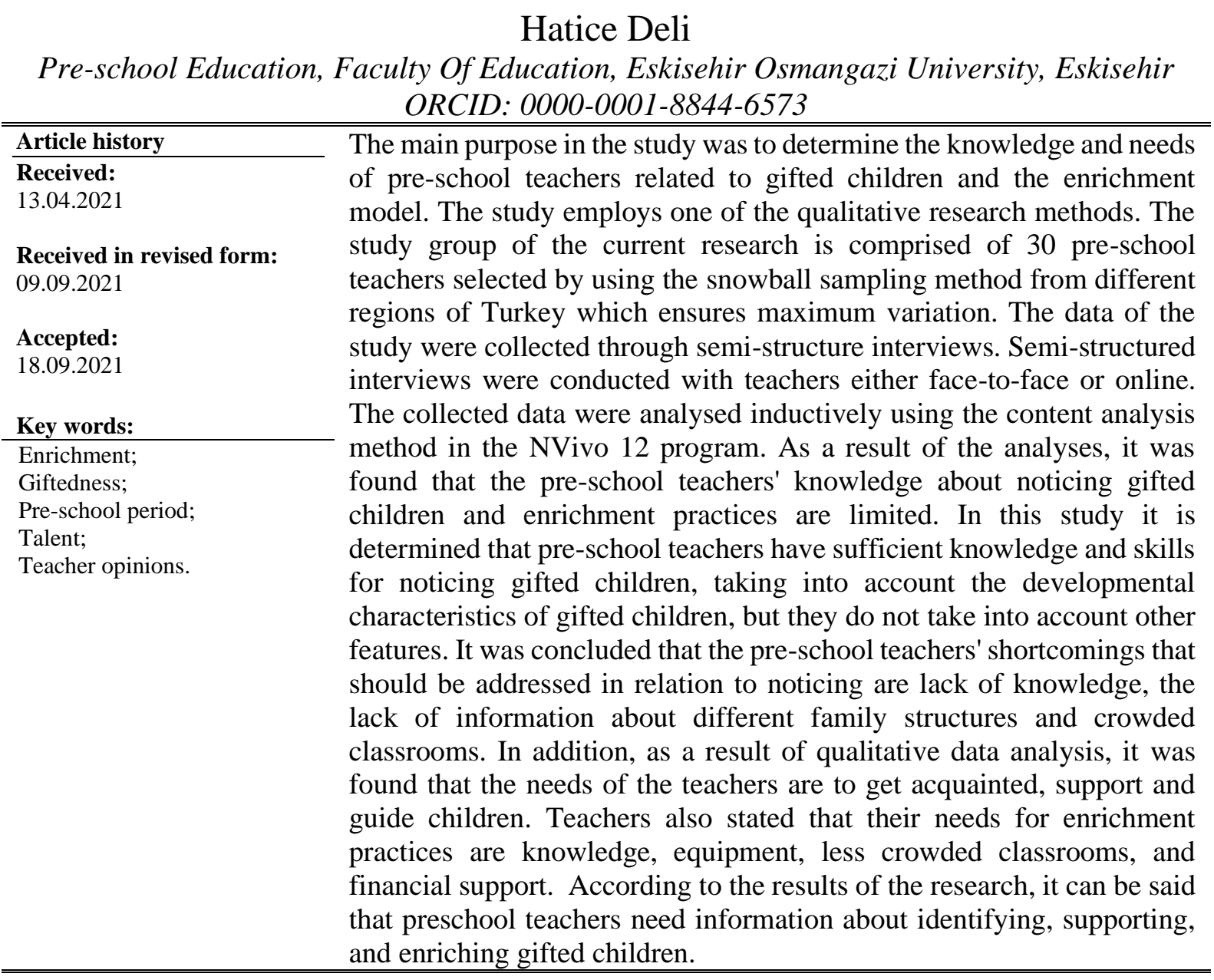

\section{Introduction}

Gifted and talented children are children who have been followed with interest at all levels of education for many years. The case of gifted and talented children through the concepts

\footnotetext{
*Correspondency: derelie@ogu.edu.tr
} 
of giftedness and talent has been attempted to be explained in different ways by theorists since the years it was first proposed. Although traditional theorists define giftedness as having a score of 140 and above in standard intelligence tests, this situation has changed over the years and the concept of gifted child has been replaced by the concept of talented child (Sak, 2017). Gagne proposed a clear distinction between the concepts of giftedness and talent and defined giftedness as an innate condition that emerges without any training; on the other hand, he defined talent as the transformation of the innate state of giftedness into well-developed skills specific to a particular field of human activity through education and training (Gagne, 2000). Renzulli explained the state of giftedness by using the Three Ring Theory and argued that giftedness is not only related with intelligence but can emerge as a result of the combination of above-average ability, motivation and creativity (Renzulli, 2000; Renzulli, 2005). Gardner proposed a different perspective of talent. Gardner states that individuals may have more than one type of intelligence, but some intelligence domains are dominant in individuals (Karabulut and Ömeroğlu, 2021). While defining the concept of intelligence, Gardner, in reality, emphasizes the talents people have. According to Gardner, intelligence is not essentially a single component, but refers to the ability to channel functions and activities in different ways in line with talents (Dağlıoğlu, 2015; Karabulut and Ömeroğlu, 2021). The Ministry of National Education defined this situation as "special talent". Accordingly, special talented individuals are individuals who develop faster in at least one area, direct societies with their characteristics such as leadership, motivation, and determination, and constitute $2 \%$ of a society (MEB, 2013). It is understood from all these definitions that the concepts of giftedness and talent are still a matter of debate. Sak (2020) explained this situation with the Fuzzy Theory and emphasized that most theories and practices of giftedness still contain uncertainty.

Karabulut and Ömeroğlu (2021), in their study where they developed a scale for nominating gifted children in early childhood, emphasize that due to the characteristics of gifted children, it is important to notice them at an early age and to provide appropriate education for their developmental characteristics in order to increase their potential (Karabulut and Ömeroğlu, 2021). According to Clark (2015), children are not born as completely gifted or talented, but most of them have great potential and this potential needs to be developed. This development is only possible by noticing gifted children at an early stage and arranging their environment and educational programs in accordance with their levels. While it is a bit easier to differentiate the educational environment for gifted children who are attending primary and secondary schools, it may be more difficult to organize the educational environments and programs of gifted children in the young age group who are defined as "young gifted children" in the preschool period. At this stage, teachers and administrators have less information about the education and educational needs of gifted children in pre-school period than about those of the gifted children in the older age groups (Wang, 1998). This lack of knowledge can both delay the noticing of gifted children and lead to the inability to differentiate education in accordance with their development. However, noticing gifted children in the early period and performing necessary early interventions are significant in terms of preventing difficulties such as academic failure and social-emotional problems that may arise in the future (Saranl1, 2017). Some studies have revealed that gifted children may not achieve academic success without educational intervention (Feldman, 1979; Wellisch \& Brown, 2012) and those educational interventions increase the success of gifted children (Kitano, 1985). Despite these studies, there are limited studies on early intervention for preschool gifted children. One of these early interventions is enrichment. The enrichment model is defined as the diversification of children's educational programs, materials, and processes by equipping them with rich content (Renzulli, 2014; Renzulli and Reis, 2014). According to Renzulli, there are three types of enrichment. To explain them briefly; the first type of enrichment involves introducing students to disciplines, subjects, 
professions, hobbies, people, events and places that are not included in the normal curriculum. In this type of enrichment, school administrators, teachers and parents try to provide experiences through speakers, films, documentaries, courses, and shows related to topics outside the curriculum. The second type of enrichment consists of materials and programs designed to develop critical and creative thinking, problem solving, communication skills and thinking skills. The third type of enrichment includes the development of skills through practice such as problem solving, planning, organizing, correct use of resources, time management and decision-making in line with their interests, research, and knowledge (Renzulli and Reis, 2010; Renzulli and Reis, 2000). In summary, type one covers general exploration activities, type two includes group training activities and type three includes individual and small group research activities of real problems (Renzulli, 2010).

Enrichment is one of the most appropriate interventions that can be applied to pre-school gifted children and can be integrated into the entire preschool curriculum (Saranl1, 2017). The MEB 2013 pre-school curriculum is a curriculum suitable for differentiating and enrichment practices with its flexibility. For these practices to be conducted, it is important to elicit the knowledge of pre-school teachers who work in different regions when it comes to the concept of gifted children, the developmental characteristics of these children and what enrichment practices might be. Moreover, to organize training seminars for pre-school teachers on enrichment for gifted children so that these practices can be successfully integrated into curriculums. Therefore, the purpose of the current study is to reveal the knowledge and needs of pre-school teachers about gifted children and enrichment practices. To gain better perspective, answers to the following questions were sought:

(1) How do preschool teachers think that they can discover gifted students and what kind of problems do they encounter in this regard?

(2) What do the pre-school teachers think about enriching the classroom environment and curriculum?

(3) What are the pre-school teachers' needs for being able to notice gifted students and to enrich the classroom environment and curriculum?

\section{Methods}

\section{Research Model}

This study was carried out by using the case study method, one of the qualitative research methods. According to Creswell (Creswell, 2013), case studies describe a situation in which the researcher collects in-depth information about a real-life, current limited system. In this study, the focus was to describe the knowledge of preschool teachers about gifted children and their needs for enrichment purposes. The semi-structured interview method was used to reveal the pre-school teachers' opinions about their needs related to noticing gifted children and enrichment practices.

\section{Sample/Study Group}

In the selection of the participants, the maximum variation sampling, one of the purposive sampling techniques, was used in the current study. In this regard, the purpose was to obtain the greatest variation in terms of professional seniority, socio-cultural and socioeconomic status of the schools where they are working, the age groups they are teaching and the type of the pre-school institutions where they are working. The participants of the study 
were reached by using the snowball technique. In the snowball technique, in the first stage, people with qualifications related to the subject of the study are determined, and in the second stage, other participants are reached through these people (Güçlü, 2019). In this study, preschool teachers working in different regions of Turkey were reached and a study group was formed by reaching other teachers through them.

Table 1. Participants' demographic features

\begin{tabular}{llll}
\hline Situation & Category & f & \% \\
\hline Education Status & Bachelor's degree & 26 & 86,67 \\
Seniority & Postgraduate degree & 4 & 13,33 \\
& $1-4$ years & 16 & 53,33 \\
& $5-9$ years & 7 & 23,33 \\
& 10 years and above & 7 & 23,33 \\
Socioeconomic Level of the School & Lower & & 33,33 \\
& Middle & 10 & 43,33 \\
Children's Age Group & Higher & 13 & 23,33 \\
& 3-4 years & 7 & 16,67 \\
School Type & 4-5 years & 5 & 40 \\
& 5-6 years & 12 & 43,33 \\
& Public school & 13 & 86,67 \\
& Private school & 26 & 13,33 \\
\hline
\end{tabular}

As can be seen in Table 1, while 4 of the 30 participating teachers hold a graduate degree, the remaining 26 teachers hold a bachelor's degree. While the number of teachers having 1-4 years of professional experience is 14 , the number of students having 5-9 years of professional experience is 6 and the number of teachers having 10 years or more of professional experience is 7. of the participating teachers, 26 are working in state schools while 4 are working in private schools. Ten of the schools where the participating teachers belong to low socio-economic status, 13 of the schools fall into the category of medium socio-economic status and 7 schools are of high socio-economic status. Five of the teachers are teaching 3-4 year-olds, 12 are teaching 4-5 year-olds and 13 are teaching 5 year-olds.

\section{Data Collection Tool}

As the data collection tool, a semi-structured interview form including items to serve the purpose of the current study was used. While preparing the semi-structured interview items, the existing research investigating teacher opinions on pre-school gifted students and enrichment practices was reviewed. As a result of this interview, a total of six interview items were developed and submitted to expert review. In light of the expert review, interview items were finalized. With these interview items, first, a pilot study was conducted on two pre-school teachers. After the pilot interviews were transcribed and their macro analysis was performed, the semi-structured interview form was finalized. The interview items are presented in Table 2.

Table 2. The purposes of the study and the interview items serving these purposes.

\begin{tabular}{ll}
\hline Purpose of the Study & Interview Items \\
\hline How do preschool teachers think that they can & $*$ How can you notice a potentially gifted child in \\
discover gifted students and what kind of problems & your classroom? What are the characteristics that \\
do they encounter in this regard? & distinguish this child from his/her typical peers? \\
& $*$ What are the problems you have experienced / may \\
& experience in noticing gifted children?
\end{tabular}


What do the pre-school teachers think about enriching the classroom environment and curriculum?
* What comes to your mind when you hear of enrichment practices in the classroom? When you have a gifted child in your classroom, what kind of enrichment activities can you do for this child?

* What comes to your mind when you hear of enriching the classroom environment?

* When you want to prepare an enriched environment for a gifted child, what should be in this environment?

* What are the topics you need to learn about to better help gifted children?

* What are the things you need and what kind of support would you like to have in order to create an enriched environment for gifted children?

\section{Data Collection and Analysis}

In the current study, interviews with the teachers were conducted face-to-face and online. In the collection of the data, when the teacher gave the required permission, the interview was recorded with a tape-recorder and when the teacher did not give this permission, the interview was recorded in writing. Each interview lasted for 30-45 minutes.

The collected data were analysed using the inductive analysis method. The data analysis was carried out by following the stages of data coding, finding themes, organizing codes and themes, and finally defining and interpreting the findings (Yıldırım and Şimşek, 2015). NVivo 12 analysis program was used for data analysis. Transcripts were added to the program. The data were divided into meaningful sections according to the purposes of the current study and interview questions and the codes that explain them were given. Codes were reviewed and similar ones were combined and classified. Themes were created as a result of these classifications. Themes derived from transcripts were submitted to expert review to increase dependability and credibility. Intercoder reliability was calculated by using the formula proposed by Miles and Huberman (2015).

$$
\text { Reliability }=\text { Number of Consensus } /+ \text { Disagreement }
$$

As a result of this calculation, the reliability was found to be $95 \%$. Based on the finalized codes and themes, the research findings were obtained, and the findings were interpreted. In addition, direct quotations to support the research findings are also given.

\section{Findings}

In this section of the study, findings obtained, and their interpretations are presented. The findings presented below are summarized in Appendix 1.

\section{Teachers' opinions about noticing gifted students}

The first purpose of the current study is to find an answer to the question "How do the pre-school teachers think that they can notice gifted students?" The codes derived from the teachers' responses to the questions of how they can notice a potentially gifted child in their classroom and what the characteristics that distinguish this child from his/her typical peers are presented in Figure 1. 


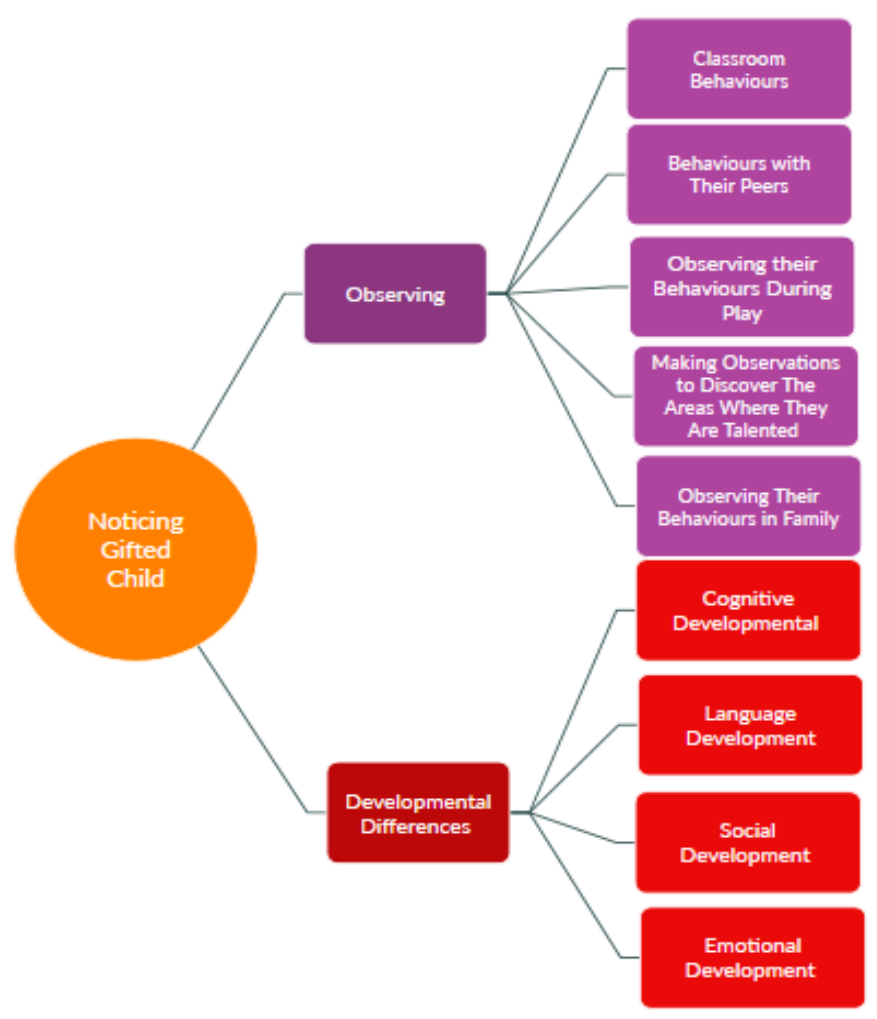

Figure 1. Codes related to noticing gifted children.

When the teachers' responses to the question "How can you notice a potentially gifted child in your classroom?" were examined, it was seen that the most popular response is "by observing in different environments.

The teachers stated that their most popular way of noticing gifted children is observing their classroom behaviours, followed by observing their behaviours with their peers, observing their behaviours during play, making observations to discover the areas where they are talented and finally observing their behaviours in family. Preschool teachers expressed the observation of classroom behaviours with the following sentences: "It can be noticed by observing his behaviour in our classroom. A child with a gifted potential grasps any situation, event or information faster and earlier than their peers."

One teacher expressed his/her opinions about observing their behaviours with their peers and observing their behaviours during play as follows: "I look at what the child likes to do by accompanying him/her during play in pre-school education."

Another teacher made observations to discover their talents, with the sentence "I think he/she can attract my attention thanks to his/her talents"; also expressed the observation of the behaviours in the family with the sentence "It can be noticed by observing the behaviours in the family"

When the teachers' responses given to the question "What are the characteristics that distinguish this child from his/her typical peers?" were examined, it was seen that the responses centred on the developmental domains of children. Teachers stated that the developmental areas where developmental differences are more clearly understood are cognitive development, language development, social development, and emotional development, respectively. 
Regarding the cognitive development domain, the following sentences were delivered "They are more inquisitive than their peers. They have a strong memory, long attention span, and have problem-solving skills."

Regarding the domain of language development, teachers explained that "the characteristics of gifted children as having a wide vocabulary, using abstract concepts in sentences, learning their native tongue faster, and making longer and more complex sentences than their peers."

Teachers stated that children may have negative social behaviours such as introversion in addition to their characteristics such as leadership in the domain of social development. One teacher explained as follows: "They can lead and manage their friends."

Teachers stated that gifted students can have a strong emotional background in the domain of emotional development: "Gifted children may have a strong emotional background about issues that are important to them. However, they may also be more sensitive to the feelings of others.

\section{The teachers' opinions about the problems they have experienced / may experience in noticing gifted children}

The pre-school teachers were asked the question "What are the problems you have experienced / may experience in noticing gifted children?". The codes created from the responses to this question are given in Figure 2.

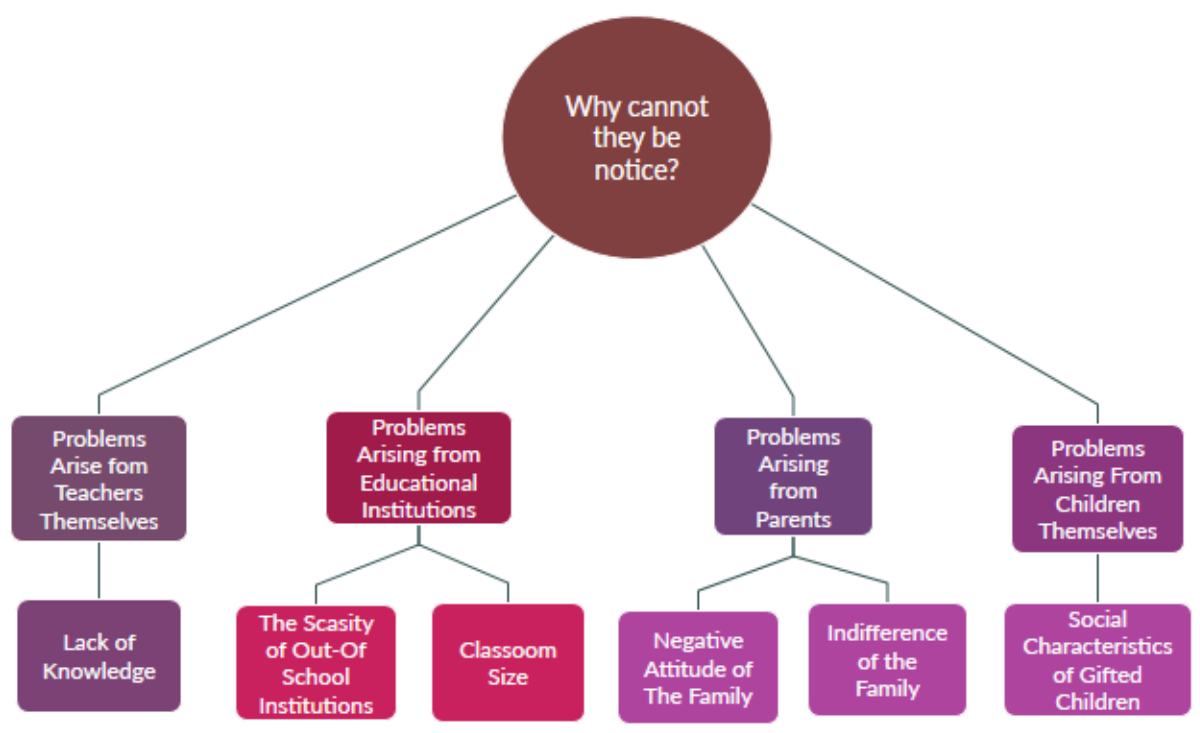

Figure 2. Codes related to the problems experienced by the pre-school teachers in noticing gifted students.

When the pre-school teachers' responses related to the problems experienced in noticing gifted students were examined, it was seen that these problems mostly arise from teachers themselves, followed by the problems arising from educational institutions, the problems arising from parents and the problems arising from children themselves. Most of the problems experienced in noticing gifted students were found to be arising from lack of knowledge on this issue on the part of the teachers. One of the teachers responded to this question as follows: "I can't notice a gifted child because I don't have detailed information on this subject. Even if I do, I may have difficulties in deciding what kind of education I will give them or how I can meet their needs." 
The scarcity of supporting institutions after school interested in gifted students and crowded classes are other problems experienced by the teachers. This situation is explained as follows: "There are not enough institutions to refer these students to and lack of support education"; they expressed their opinions on crowded classes as follows: "with increasing number of students in each class, we have less chance to address the individual needs of children. Lack of close attention to students will result in our having less information about the subjects they are interested in/curious about."

Moreover, negative attitudes of the family and indifference of the family can be counted among other problems. One of the teachers explained this situation as follows: "When I talk about this issue with the family, they consider sending their child to get extra courses as a burden and rather than supporting us, they just say "how nice", and that's all".

One of the problems experienced by the teachers in noticing gifted children is tied to childrelated reasons. Indeed, the social characteristics of gifted children pose a problem in determining these children. One of the teachers responded to this question as follows: "It is highly possible to confuse these children with social individuals as their social characteristics and their areas of interest are different from other individuals."

\section{Pre-school teachers' opinions about enriching the classroom environment and curriculum}

In the current study, the following questions were asked to the teachers to elicit their opinions about enriching the classroom environment and curriculum; "What comes to your mind when you hear of enrichment practices in the classroom?", "When you have a gifted child in your classroom, what kind of enrichment activities can you do for this child?", "When you want to prepare an enriched environment for a gifted child, what should be in this environment?" The codes derived from the teachers' responses to these questions are given in Figure 3.

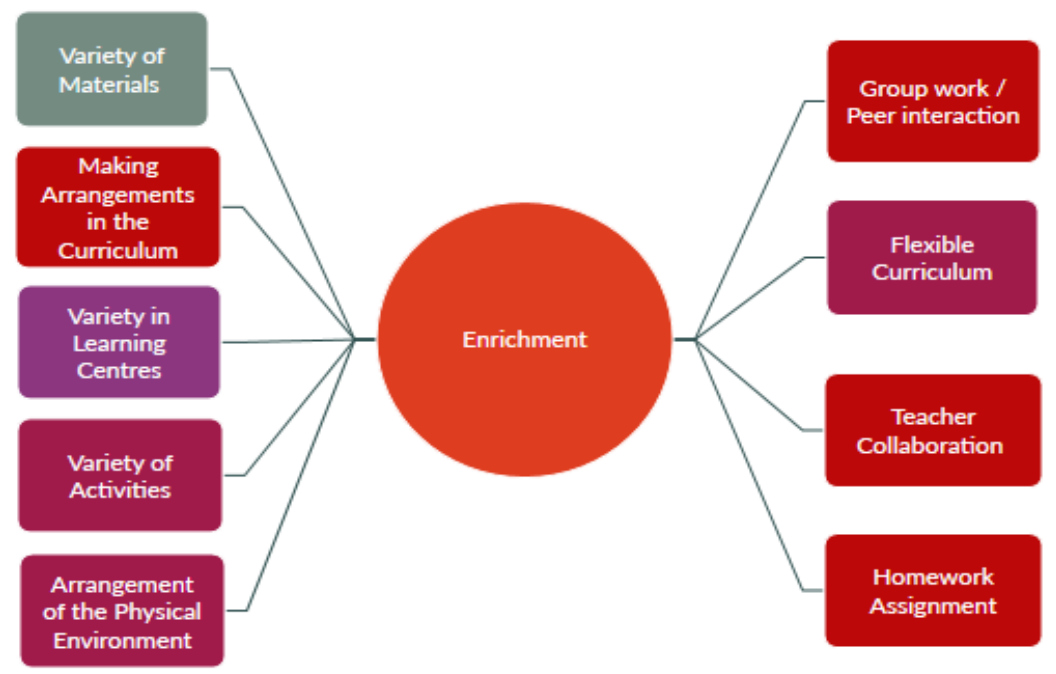

Figure 3. Codes related to the pre-school teachers' opinions about enrichment.

When the opinions of the pre-school teachers about enriching the classroom environment and the curriculum were examined, it was seen that the greatest emphasis was put on the variety of materials and then on making adaptations in the curriculum, followed by the variety in learning 
centres, variety of activities, arrangement of the physical environment, group work/peer interaction, flexible curriculum, teacher collaboration and homework assignment.

Within the code of the material diversity, the greatest emphasis was put on the sub-code of mind and intelligence games. One of the teachers expressed his/her opinions about this sub-theme as follows: "I purchase a variety of mind and intelligence games and use them for enrichment activities. "In relation to the code of making arrangements in the curriculum, one of the teachers expressed his/her opinions as follows: "Individualized curriculums can be prepared; activities more difficult than the level of the class can be prepared for these children".

One of the sub-codes stated by the teachers related to enrichment is the diversification of learning centres. One of the teachers expressed his/her opinions on this issue as follows:

"I add books to the book centre to improve the vocabulary of children. In the block centre, I add blocks so that they can play different block-building games. I add materials to the science and math centre so that children can see different ways of problem solving and thus their thinking skills can be fostered."

Another sub-code found in this code is the variety of activities. One of the teachers expressed his/her opinions about this sub-code as follows: "I can increase the activities appealing to his/her interests and talents, moreover, I can plan a special activity for him/her which is more difficult than the activities given to other children."

The other sub-codes found in this code include the arrangement of the physical environment, group works/peer interaction, flexible curriculum, teacher cooperation and homework assignment. Teachers expressed their opinions about the arrangement of the physical environment as follows: "Adding more stimuli to the physical environment, creating extra activities to meet the interests and needs of gifted children"; about group works/peer interaction; "they can be brought together with other gifted students in a classroom environment so that they can interact with each other and share something"; about a flexible curriculum; "a flexible curriculum, child-centred learning, projects to be performed by children in compliance with their interests and wishes, and designing an environment where they can exchange ideas with the teacher while cooperating with their peers"; about teacher cooperation; "We can plan and design educational environments through cooperation with teachers working in institutions such as RAM (Guidence and Research Center) and BILSEM (Science and Art Centers) where special education is offered to gifted children" and about homework assignment; "I can assign homework to motivate them to do research in line with their interests and talents".

\section{The pre-school teachers' opinions about their needs for being able to notice gifted students}

In order to elicit the pre-school teachers' opinions about their learning needs for being able to notice gifted students, they were asked the following questions: "What are the topics you need to learn about to better help gifted children?" Codes created from findings related to the subject are given in Figure 4. 


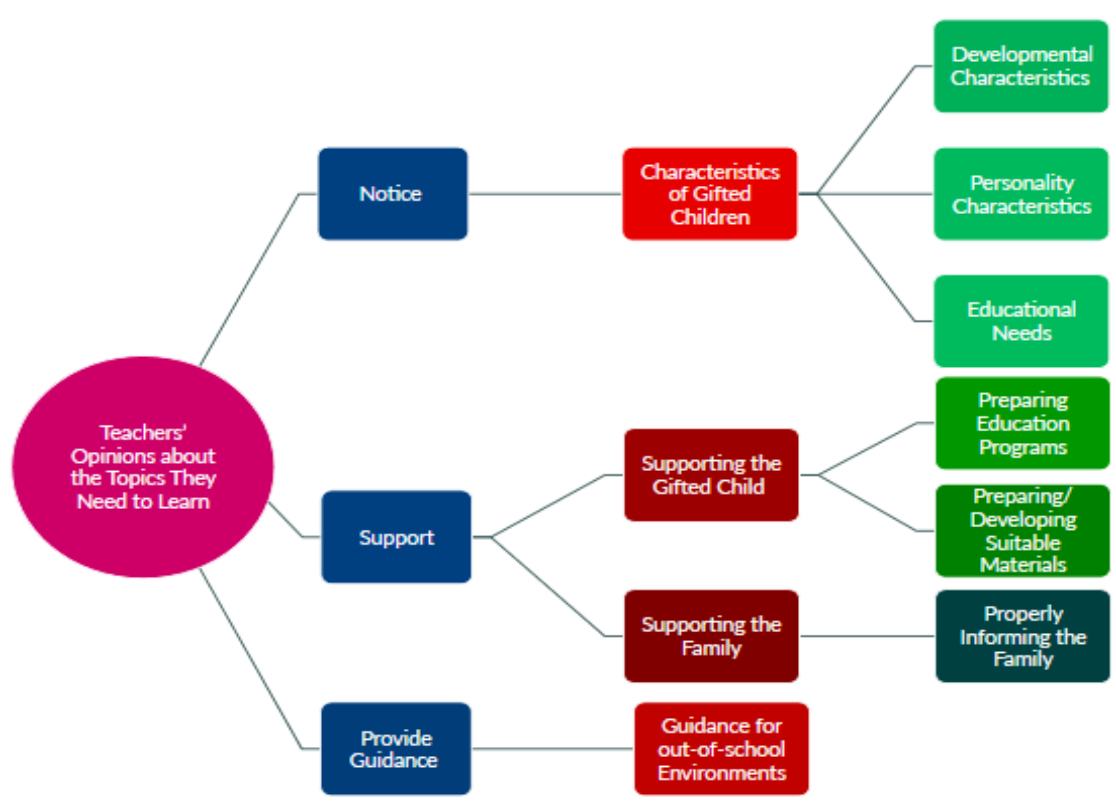

Figure 4. Codes related to the pre-school teachers' opinions about the topics they need to learn about to better help gifted children

The pre-school teachers stated that what they need most is to learn about how to notice gifted students. In this regard, they stated that they need to be informed about the sub-codes of the developmental characteristics of gifted children, their personality characteristics, and educational needs. One of the teachers expressed his/her needs in relation to knowing the developmental and personality characteristics of gifted children as follows: "We may need to be informed about the developmental characteristics and personality characteristics of gifted students. Moreover, we may need some guidance on what kind of approach should be adopted towards these children".

In the sub-theme of educational needs, one of the teachers expressed his/her opinions as follows: "I need to know what their needs are, what kind of communication I should establish with them and what materials they need."

The pre-school teachers stated that they need to learn how to support gifted children. This code of support is divided into two sub-codes called supporting the gifted child and supporting his/her family. The sub-code of supporting the gifted child involves preparing education programs suitable for these children and preparing/developing suitable materials. A teacher explained this sub-theme as follows: "I need information on his/her communication with his/her peers in training programmes."

In relation to the sub-code of supporting the child, one of the teachers stated "I would like to learn in detail how to support gifted students after they have been identified. If I cannot provide the appropriate education, I can't increase his/her potential and thus the child may not recognize his/her capacity."

The sub-code of supporting the family, which is another sub-code, includes informing the family correctly. For example, a preschool teacher explains this sub-code as follows: "I think that I am not able to inform the parents of gifted students. I think that as a teacher, I am not qualified to guide parents on how parents should approach their gifted children. I need well- 
equipped information on this subject."

Thirdly, the pre-school teachers stated that they have learning needs about how to provide guidance to gifted students. The sub-code found under the code of providing guidance to gifted children is out-of-school environments.

One of the teachers expressed his/her opinions about the code of providing guidance to gifted students as follows; "How can I discover gifted students? How should I approach a gifted child? Which institutions should I refer them to? What kind of learning environment should I establish for a gifted student and whose support should I seek?"

\section{The pre-school teachers' opinions about their needs for enriching the classroom environment and curriculum}

In order to elicit the pre-school teachers' opinions about their needs for enriching the classroom environment and curriculum for gifted children, they were asked the following question: "What are the things you need and what kind of support would you like to have in order to create an enriched environment for gifted children?" The codes derived from the responses of the teachers to this question are presented in Figure 5.

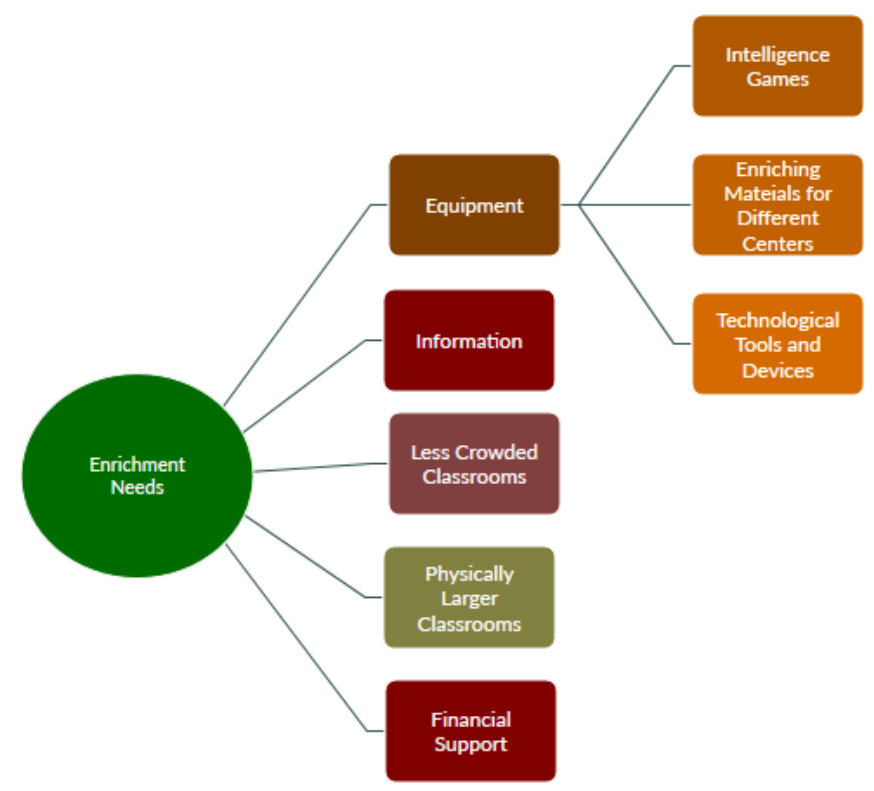

Figure 5. Codes related to the pre-school teachers' needs for enrichment practices.

In relation to their needs for enriching the classroom environment and curriculum, the preschool teachers put the greatest emphasis on their needs for equipment. The sub-codes created in line with the opinions of preschool teachers are as follows: "Mind and intelligence games, drama, creativity" and materials for developing mind and intelligence games; "to enrich the centers and to create temporary learning centers" with enriching materials for different centres; "tablets and computers should be included in the educational environments of these children" with technological tools and equipment. 
One of the pre-school teachers expressed his/her opinions on this code as follows:

"There should be functional and different materials, yet these materials should be brought to the classroom and kept there for a specific period of time and they should be removed from the classroom environment rather than permanently being kept there and then new materials should take their place so that these children should not lose their interest. Activities can be adapted in line with the recommendations of the family or the teachers from BILSEM if the child attends BILSEM (Science and Art Centers). When necessary, financial support of the families can be sought for the provision of materials."

In addition to their needs for equipment, the pre-school teachers also stated that they need information as follows: "In order to prepare this environment, it is very important to get information and application support first", about less crowded classrooms; "independent study areas, less class sizes", about physically larger classrooms; "The classroom must be physically larger" and about financial support; "We need financial support for such enrichment efforts."

Secondly, the teachers also stated that they have lack of information about enrichment and that they would like to receive training on this issue. In this connection, one of the pre-school teachers expressed his/her opinions as follows: "I need to work in collaboration with experts in the field. I need support on what kind of materials should I use, how should I use them, how can I obtain them, how can I enrich my explanations."

Finally, they stated that they need physically larger classrooms and financial support to enrich their classrooms. One of the teachers expressed his/her need for financial support as follows:

"There is a need for art activities, workshops, technical equipments and materials to develop their thinking skills, a centre of mind and intelligence games, sports activities, drama activities in the class, robotic coding and science experiments. To do so, we need financial support, teacher training activities and in-service courses."

One of the pre-school teachers expressed his/her need for better classroom conditions as follows: "There should be a variety in learning environments, materials should be continuously renewed. School administrations and families should support us for the necessary materials. There should be a setting like a laboratory in pre-school institutions for these children." Another teacher expressed his/her opinions as follows: "I need information and equipment to support the child, independent study areas, less crowded classrooms and teachers who are experts in their field."

\section{Discussion}

In the current study, the teachers stated that they could notice gifted children by detecting their developmental differences from their peers through the observation method. They stated that they used the observation method in the form of classroom observation, peer observation, and observation of family behaviours. Similar results were obtained in other studies on the subject (Bildiren et all, 2020; Dağlığlu, Turupçu-Doğan \& Basit, 2017). According to this studies, preschool teachers stated that they can use the observation technique the most in identifying gifted children, but secondly, standardized tests can be applied by experts. The reason why they mostly prefer observation is that they think they are deficient in applying other methods (Bildiren et all, 2020). Current study results shows that the pre-school 
teachers use only the observation method and do not use other methods in noticing gifted children and that they have deficiencies and inadequacies in making use of multiple assessments. Although teacher observation has an extremely important place in identifying gifted children (Chan, 2000), it is seen that the evaluation of portfolio files, which has an important place especially in getting to know children and allows multiple assessments, and standard tests for identifying gifted children are ignored. In the study conducted by Schroth and Helfer (2008), it was emphasized that teacher observations, portfolio files and performancebased evaluations are important for determining gifted children in the pre-school period.

The pre-school teachers stated that gifted children have different characteristics in the domains of cognitive, linguistic, social and emotional development from other children. In this connection, the pre-school teachers stated that the main characteristics that distinguish gifted children from other children in the domain of cognitive development are their being very inquisitive and asking a lot of questions, imagination and strong memory. Gifted children have characteristics such as reasoning, creativity, curiosity, problem solving skills, and not being content with the answers to the questions they ask at an early age (Bildiren, 2018; Clark, 2015; Gür, 2017; Levent, 2013). These characteristics stated in the literature are consistent with the responses given by the preschool teachers regarding the cognitive development of gifted children. The pre-school teachers stated that the main features that distinguish gifted children from other children in the field of language development are their wide vocabulary, their ability to use abstract concepts in sentences, their native language learning speed, and their ability to make longer and more complex sentences than their peers. When the language development of gifted children in pre-school period is examined, it is seen that they can speak earlier and make more complex sentences than children with normal development (Vaivre Douret, 2011). In the literature, it is also stated that they can have long and extensive discussions on a topic (Smutny, 2000), that they can understand metaphorical discourses (Castillo, 1998), that some gifted children expect to make a complete sentence until the age of 3-4 due to their perfectionism and that their first sentences are long, complex sentences (Silverman, 1981). These characteristics stated in the literature are consistent with the responses given by the pre-school teachers regarding the language development of gifted children. The pre-school teachers stated that the main characteristics that distinguish gifted children from other children in the domains of social and emotional development are leadership, introversion and strong emotional structure. When the social and emotional characteristics of gifted children are examined, it is seen that they have the characteristics of social isolation, perfectionism, introversion (Saranlı \& Metin, 2012), questioning rules and understanding and feeling an unfair situation from an early age (Clark, 2015), questioning the world and what is happening around them rather than accepting them as they are, approaching the events with an intense sense of sensitivity, having high self-esteem, emotional intensity and sensitivity (Özbay \& Palanc1, 2011). It can be said that the reason why preschool teachers mostly focus on cognitive development is that the concept of giftedness is associated with the concept of giftedness (Sak, 2017). In this context, the characteristics that teachers use to define students seem compatible with the literature. In this respect, it can be stated that teachers can distinguish students.

The pre-school teachers did not express any opinions about the physical and motor development of gifted children. While no difference has been stated in some of the studies in relation to the physical development of gifted children (Louis, 2005; as cited by Vaivre Douret), some studies have revealed that they can sit unsupported earlier than their typical peers (Gross, 1999) and walk about a month earlier (Terman, 1935). However, there is no literature information about the physical characteristics of gifted pre-school children. The reason for this is that the differences in the physical development of gifted children are not very evident, and the physical 
differences at younger ages cannot be generalized to later periods due to the lack of longitudinal studies (Gür, 2017).

These results obtained from the current study show that the pre-school teachers have sufficient knowledge and skills for noticing gifted children, taking into account the developmental characteristics of gifted children. According to the Pre-school Period Gifted Candidate Notification Scale developed by Bildiren and Bilgen (2018), noticing gifted children in the preschool period consists of three dimensions; general mental ability, creativity and motivation (commitment to work). However, it was determined that the pre-school teachers made evaluations according to the general ability dimension to notice gifted children. General mental ability characteristics constitute a very important area in identifying gifted children in early childhood and should be used as a criterion in identifying gifted children (Heller, 2004; Karabulut and Ömeroğlu, 2020). In addition, it maintains its weight as a determining factor in many of today's giftedness theories (Sak, 2017). The pre-school teachers' responses regarding the identification of gifted children in the early childhood period are compatible with general giftedness characteristics defined in the literature. Bildiren (2018), Karabulut and Ömeroğlu (2020), and Kuo, June, and Suve Hu (2010) have demonstrated that questioning, abstract thinking, curiosity, broad knowledge capacity, future-oriented thinking, and strong memory characteristics are clearly observed in young gifted children. However, in the current study, none of the responses given by the pre-school children were observed to include statements regarding creativity and motivation (commitment to work) in terms of noticing giftedness in the early childhood period. The reason why there are no responses about creativity is thought to be that as these children are not in the stage of reality, their perspectives of events are different and gifted children in the early childhood period can only complete a few stages of creativity earlier than their peers with normal development (Sak, 2016). Motivation subdimension is explained by characteristics such as perseverance, desire, interest, deep interest in a field (Renzulli, 2016). It can be said that the reason for the low motivation response is the limited enrichment studies and special education programs for children with potential in early childhood. In addition, this situation may be caused by the perception of children's being curious about a certain subject, questioning and working hard as their general abilities in early childhood period.

The pre-school teachers expressed the enrichment practices that could be made for these children as material enrichment, changes in curriculums, enrichment in learning centres and variety of activities. In its simplest definition, enrichment is the replacement of curriculums and educational materials with in-depth subject content (Renzulli, 2014; Şahin, 2018; Sak, 2017). This differentiation includes compacting the curriculum according to each child's own pace, removing the previously learned subjects and enriching the materials according to the interests of students (Darga, 2018; Renzulli and Reis, 1997; Şahin, 2018). The definition of enrichment is in compliance with the statements of the pre-school teachers arguing that the classroom environment and curriculum should be enriched, variety should be brought to learning centres, variety should be brought to activities, learning environments should be re-arranged, peer interaction should be fostered, the curriculum should be made flexible and variety should be brought to homework. When the answers given by the preschool teachers to the relevant question are examined, it can be said that they have information about what enrichment is, but they have limited information about what can be done for enrichment. In the current study, the pre-school teachers explained how they can enrich materials by stating "I keep variety of mind and intelligence games" in the classroom and how they provide enrichment through homework by stating "I assign homework related to the subject being studied". They did not give detailed information about the other codes, however. The enriched classroom environment is like a 
well-equipped laboratory or workshop that allows instant access to many learning activities. In this environment, small group activities can be designed for more children to interact with each other, and weekly project activities can be assigned homework to reinforce what they have learned in these activities (Darga, 2018; Hallahan and Kaufman, 2003). In the study conducted by Saranl1 (2017), pre-school teachers who previously had gifted children in their class stated opinions about enrichment practices including the provision of multiple stimuli, generating a sense of belongingness to the classroom, allowing them to progress at an individual pace. While Saranlı (2017) stated that the teachers having gifted children in their classes have adequate knowledge about enrichment practices, in the current study, it was found that the pre-school teachers working with children showing a normal development have restricted knowledge about enrichment.

In the current study, the topics that the pre-school teachers need to learn about related to gifted children were also examined. It was found that the needs of the teachers are to know, support and guide children. In noticing gifted children, most of the teachers stated that gifted children in early childhood have developmental differences from other children, but they have difficulty in determining their typical characteristics. They also stated that even though they notice these children, they do not know what their needs are. The pre-school teachers stated that they have difficulties in preparing an appropriate educational program for gifted children and preparing / developing appropriate materials and that they need support. They also stated that they need support and information on how to provide appropriate information for the families of gifted children. The pre-school teachers stated that they need support and information about which institutions and organizations they could refer gifted children to. According to the results obtained from the current study, we can say that the pre-school teachers have very little information about how to support gifted children and they have a lot of educational needs on this issue. The reason for this may be the fact that the issue of gifted students in the early childhood period has recently come to the agenda of Turkey and thus, it was not addressed in the pre-school teacher training programs until recently (YÖK, Council of Higher Education, 2018). Parallel to the findings of the current study, Özcan and Gülkaya (2019), in their study conducted to determine the educational needs of pre-school teachers of gifted children, found that pre-school teachers do not have adequate knowledge about gifted students and that they need training about a lot of subjects (materials selection, measurement and evaluation, creating a suitable learning environment, etc.).

Pre-school teachers stated that they need information, equipment, financial support, physically larger classes and less crowded classes for better enrichment practices. According to the results obtained from the current study, it can be argued that the pre-school teachers have very little knowledge about enrichment practices. For enrichment practices, as many kinds of materials as possible in accordance with children's learning styles should be provided, and programs and contents should be created in which they can use these materials. Gifted children should be supported to produce products by giving them the opportunity to create reports, projects, experiments, exhibitions on the subject they are working on (Dağlioğlu, 2010).

\section{Results and Suggestions}

According to the results obtained from the findings of the current study, it can be said that the knowledge of the pre-school teachers about noticing gifted children partially concurs with what has been reported in the literature, but there are points in which they are lacking. On the other hand, it can be argued that there is a lack of knowledge about enrichment practices on the part of the pre-school teachers. It is necessary to notice gifted children at an early age and 
to organize and differentiate their education in line with their interests and talents. However, the limited knowledge of pre-school teachers about enrichment for gifted children in this period may cause children to be deprived of these practices. For this reason, in-service trainings and courses can be organized on subjects that preschool teachers need to learn about related to gifted children. In order for pre-school teachers to have detailed information about the characteristics of gifted children, these subjects can be included in detail in their undergraduate programs. The pre-school teachers stated their needs for enrichment practices as information, equipment, financial support, and less crowded classes. Therefore, it should be contributed to the conduct of enrichment practices for gifted children in pre-school period by meeting the needs stated by the pre-school teachers. In the current study employing the qualitative research design, interviews were conducted with a limited number of teachers. Further research can be conducted on larger samples by using the mixed research method, having both qualitative and quantitative dimensions. Pre-school teachers can be given in-service training focused on enrichment practices and they can be allowed to apply what they have learned from such trainings in the classroom environment to see their results.

\section{References}

Bildiren, A. (2018). Developmental characteristics of gifted children aged 0-6 years: parental observations. Early Child Development and Care, 188(8), 997-1011.

Bildiren, A., B1kmaz Bilgen, Ö. (2019). Okul öncesi dönem üstün yetenekli çocuklar için aday bildirim ölçeği: geçerlik ve güvenirlik çalışması. [Candidate notification scale for gifted children in pre-school period: validity and reliability studies]. Ankara University Faculty of Educational Sciences Journal of Special Education. 20(2), 269-289. DOI: 10.21565/ozelegitimdergisi.475278

Bildiren, A., Gür, G., Sağkal, A. S., \& Özdemir, Y. (2020). The perceptions of the preschool teachers regarding identification and education of gifted children. Ankara University Faculty of Educational Sciences Journal of Special Education, 21(2), 329-356. DOI: 10.21565/ozelegitimdergisi.572326

Chan, D. W. (2000). Exploring identification procedures of gifted students by teacher ratings: Parent ratings and student self-reports in Hong Kong. High Ability Studies, 11(1), 6982. DOI: $10.1080 / 713669176$

Clark, B. (2015). Üstün Zekâlı Olarak Büyümek. [Growing Up Gifted]. (F. Kaya, \& Ü. Ogurlu, Çev.) Nobel Publishing.

Creswell, J.W. (2013). Nitel araştırma yöntemleri. [Qualitative research methods.] M. Bütün ve S. B. Demir (Çev. Ed.). Siyasal Bookstore.

Dağlığlu, H . (2010). Üstün yetenekli çocuklarin eğitiminde öğretmen yeterlikleri ve özellikleri. [Proficiency and characteristics of teachers in the education of gifted children]. Journal of Ministry National Education, 40 (186), 72-84. https://dergipark.org.tr/tr/pub/milliegitim/issue/36198/407059

Dağlığlu, H. E. , (2015). Erken Çocuklukta Üstün Yetenek. [Giftedness in Early Childhood]. Üstün Zekalı Ve Yetenekli Çocukların Eğitimi [Education of Gifted and Talented Children ]. (pp.75-96), Pegem Akademi Publishing.

Darga, H. (2018). Üstün Zekalı/Yetenekli Çocuklara Erken Çocuklukta Uygulanabilecek Eğitim Modelleri ve Uygulama Örnekleri. [Educational Models and Practice Examples For Gifted/Talented Children in Early Childhood]. (A. Ataman, Ed.). Üstün Zekalılar Ve Üstün Yetenekliler Konusunda Bilinmesi Gerekenler. [Need to Know About Gifted and Talented]. (pp.87-118). Vize Publishing.

Dağlioğlu, H. E., Doğan, A. T., \& Basit, O. (2017). Kapsayıcı Okul Öncesi Eğitim Ortamlarında Öğretmenler Çocukların Bireysel Yeteneklerini Belirlemek ve Geliştirmek İçin Neler 
Yapıyor?. [What Do Teachers Do to Identify and Develop Children's Individual Talents in Inclusive Preschool Education Environments?]. Gazi University Gazi Faculty of Education Journal, 37(3), 883-910.

Feldman, D. (1979). The mysterious case of extreme giftedness. Teachers College Record, 80(5), 335-351.

Gagné, F. (2000). Understanding the complex choreography of talent development through DMGT-based analysis. International handbook of giftedness and talent, 2, 67-79.

Güçlü, İ. (2019). Sosyal bilimlerde nitel araştırma yöntemleri. [Qualitative Research Methods In The Social Sciences]. Nobel Publishing.

Gür, Ç. (2017). Eğitimsel ve Sosyal-Duygusal Bakış Açılarıyla Üstün Yetenekli Çocuklar. [Gifted Children from Educational and Social-Emotional Perspectives]. An1 Publishing.

Hallahan, D.P. \& Kaufman, J., M. (2003). Exceptional learners: Introduction to special education. 12th ed. Allyn and Bacon- Hays/Monkmeyer.

Smutny, J. F. (2000). Teaching young gifted children in the regular classroom. ERIC Clearinghouse on Disabilities and Gifted Education.

Castillo, L. C. (1998). The effect of analogy instruction on young children's metaphor comprehension. Roeper Review, 21(1), 27-31.

Silverman, L. (1981). Early signs of giftedness. http://australiangiftedsupport.com

Heller, K.A. (2004). Identification of gifted and talented students. Psychology Science, Volume $46(3)$, p. $302-323$.

Karabulut, R., \& Ömeroğlu, E. (2021). A validity and reliability study of a nomination scale for identifying gifted children in early childhood: A validity and reliability study of a nomination scale. International Journal of Curriculum and Instruction, 13(2), 17561777.

Kitano, M. K. (1985). Issues and problems in establishing preschool programs for the gifted. Roeper Review, 7(4), 212-213.

Kuo, C. C., Maker, J., Su, F. L., \& Hu, C. (2010). Identifying young gifted children and cultivating problem solving abilities and multiple intelligences. Learning and Individual Differences, 20(4), 365-379. DOI:10.1016/j.lindif.2010.05.005

Levent, F. (2013). Üstün yetenekli çocukları anlamak. [Understanding gifted children]. Nobel Publishing.

MEB. (2013). Okul Öncesi Ë̆itim Programı. [Preschool Education Program].

MEB. (2013). Özel Yetenekli Bireyler Strateji ve Uygulama Plan1 2013-2017. [Specially Talented Individuals Strategy and Implementation Plan]. Ministry of National Education Special Education Services and General Directorate.

Miles, M. B. ve Huberman, A. M. (2015). Nitel veri analizi. [Qualitative data analysis]. (S. Akbaba Altun ve A. Ersoy, Ed. ve Çev.). Pegem Akademi Publishing.

Özbay, Y., \& Palancı, M. (2011). Üstün yetenekli çocuk ve ergenlerin psikososyal özellikleri. [Psychosocial characteristics of gifted children and adolecents]. Sakarya University Journal of Education Faculty (22), 89-108.

Özcan, D , Gülkaya, Ş . (2019). Okul öncesi öğretmenlerinin üstün yetenekli çocuklara yönelik algi ve eğitim ihtiyaçlarinin belirlenmesi. [Determination of preschool teachers' perceptions and training needs towards gifted and talented]. Kastamonu Education Journal, 27 (5), 2355-2368 . DOI: 10.24106/kefdergi.3776

Renzulli, J. S. (2005). The Three-Ring Conception of Giftedness. In R. J. Sternberg, \& J. E. Davidson (Eds.), Conceptions of giftedness (s. 246-279). Cambridge University Press.

Renzulli, J. S., \& Reis, S. M. (2000). The schoolwide enrichment model. International handbook of giftedness and talent, 2, 367-382. 
Renzulli, J. S. (2000). The identification and development of giftedness as a paradigm for school reform. Journal of Science Education and Technology, 9(2), 95-114. http://dx.doi.org/10.1023/A:1009429218821

Renzulli, J. S., \& Reis, S. M. (2014). The schoolwide enrichment model: A how-to guide for talent development. Sourcebooks, Inc.

Renzulli, J. (2014). The schoolwide enrichment model: a comprehensive plan for the development of talents and giftedness. Revista Educação Especial, 27(50), 539-562.

Renzulli, J. S., \& Renzulli, S. R. (2010). The schoolwide enrichment model: A focus on student strengths and interests. Gifted Education International, 26(2-3), 140-156.

Renzulli, J. S., \&; Reis, S. M. (1997). The Schoolwide Enrichment Model: A How-to Guide for Educational Excellence. Creative Learning Press, Inc., PO Box 320, Mansfield, CT

Sak, U. (2017). Üstün Zekâlılar Özellikleri Tanılanmaları Eğitimleri. [Gifted Characteristics Diagnosis Trainings]. Vize Publishing.

Sak, U. (2020). Üstün yetenek kavramının belirsizliğinden ortaya çıkan bulanık kuram. [Fuzzy Conception of Giftedness born out of the fuzziness of giftedness]. New Turkey Journal, $115,99-108$.

Saranlı, A. (2017). Okul öncesi dönemdeki erken müdahale uygulamalarına farklı bir bakış: üstün yetenekli çocuklar için erken zenginleştirme. [A different perspective to the early intervention applications during preschool period: early enrichment for gifted children]. Education and Science, 42(190). doi:http://dx.doi.org/10.15390/EB.2017.7062

Saranli, A. G., \& Metin, N. (2012). Üstün yetenekli çocuklarda gözlenen sosyal-duygusal sorunlar. [Social-emotional problems observed in gifted children]. Ankara University Journal of Faculty of Educational Sciences, 45(1), 139-163.

Schroth, S. T., \& Helfer, J. A. (2008). Identifying Gifted Students: Educator Beliefs regarding Various Policies, Processes, and Procedures. Journal for the Education of the Gifted, 32(2), 155-179. https://doi.org/10.4219/jeg-2008-850

Şahin, F. (2018). Özel yetenekli ögrenciler ve eğitimleri. [Gifted students and their education.]. An1 Publishing.

Terman, L. M. (1925). Mental and Physical Traits of a Thousand Gifted Children: in Genetic Studies of Genius. vol. 1. Standfort University Press.

Vaivre-Douret, L. (2011). Developmental and cognitive characteristics of "high-level potentialities"(highly gifted) children. International Journal of Pediatrics, 2011.

Wang, W. L. (1998). Teachers' attitudes toward gifted preschoolers and their knowledge of the early intervention for the gifted (Doctoral dissertation), The Ohio State University

Wellisch, M., \& Brown, J. (2012). An Integrated Identification and Intervention Model for Intellectually Gifted Children. Journal of Advanced Academics, 23(2), 145167. https://doi.org/10.1177/1932202X12438877

Yıldırım, A. ve Şimşek, H. (2000). Sosyal bilimlerde araştırma yöntemleri. [Research methods in social sciences]. Seçkin Publishing.

YÖK. (2018). Okul Öncesi Öğretmenliği Lisans Programı. [Pre-School Teacher Education Program]. 
Appendix 1. Summary Findings

\begin{tabular}{|c|c|c|c|}
\hline $\begin{array}{l}\text { Findings } \\
\text { Teachers' } \\
\text { opinions } \\
\text { about } \\
\text { noticing } \\
\text { gifted } \\
\text { students }\end{array}$ & & & \multirow[b]{2}{*}{$\begin{array}{l}\text { Examples } \\
\text { observing his/her } \\
\text { behavior in our } \\
\text { classroom. } \\
\text { I look at what the child } \\
\text { likes to do by } \\
\text { accompanying him/her } \\
\text { during activity. }\end{array}$} \\
\hline \multirow[t]{8}{*}{$\begin{array}{l}\text { Teachers' } \\
\text { opinions } \\
\text { about } \\
\text { noticing } \\
\text { gifted } \\
\text { students }\end{array}$} & \multirow[t]{4}{*}{ Observing } & Classrom Behaviours & \\
\hline & & Observing their behaviours during play & $\begin{array}{l}\text {...observing him/her } \\
\text { interacting with his/her } \\
\text { peers during play. }\end{array}$ \\
\hline & & $\begin{array}{l}\text { Making observations to discover the } \\
\text { areas where they are talented }\end{array}$ & $\begin{array}{l}\text {...he/she can attract my } \\
\text { attention thanks to his/her } \\
\text { talents }\end{array}$ \\
\hline & & Observing their behaviours in family & $\begin{array}{l}\text {....observing the } \\
\text { behaviors in the family }\end{array}$ \\
\hline & \multirow[t]{4}{*}{$\begin{array}{l}\text { Developmental } \\
\text { differences }\end{array}$} & Cognitive development & $\begin{array}{l}\text {...They have a strong } \\
\text { memory, long attention } \\
\text { span... }\end{array}$ \\
\hline & & Language development & $\begin{array}{l}\text {... gifted children having } \\
\text { a wide vocabulary, using } \\
\text { abstract concepts in } \\
\text { sentences... }\end{array}$ \\
\hline & & Social development & $\begin{array}{l}\text { They can lead and } \\
\text { manage their friends. }\end{array}$ \\
\hline & & Emotional development & $\begin{array}{l}\text { They have a strong } \\
\text { emotional background } \\
\text { about issues that are } \\
\text { important to them. }\end{array}$ \\
\hline \multirow{5}{*}{$\begin{array}{l}\text { The } \\
\text { teachers' } \\
\text { opinions } \\
\text { about the } \\
\text { problems } \\
\text { they have } \\
\text { experienced } \\
\text { / experience } \\
\text { in noticing } \\
\text { gifted } \\
\text { children }\end{array}$} & $\begin{array}{l}\text { Problems arise } \\
\text { from teachers } \\
\text { themselves }\end{array}$ & Lack of knowledge & $\begin{array}{l}\text {..I do not have detailed } \\
\text { information on this } \\
\text { subject.... }\end{array}$ \\
\hline & $\begin{array}{l}\text { Problems } \\
\text { arising from } \\
\text { educational } \\
\text { institutions }\end{array}$ & $\begin{array}{l}\text { The scarcity of out of school } \\
\text { institutions } \\
\text { Classroom size }\end{array}$ & $\begin{array}{l}\text { There are not enough } \\
\text { institutions to refer these } \\
\text { students to... } \\
\text {... With increasing number } \\
\text { of students in each class, } \\
\text { we have less chance to } \\
\text { address the individual } \\
\text { needs of children... }\end{array}$ \\
\hline & \multirow[t]{2}{*}{$\begin{array}{l}\text { Problems } \\
\text { arising from } \\
\text { parents }\end{array}$} & Negative attitude of the family & $\begin{array}{l}\text {...negative attitude of the } \\
\text { family and high-level } \\
\text { expectations from the } \\
\text { childs above the their } \\
\text { performans }\end{array}$ \\
\hline & & Indifference of the family & $\begin{array}{l}\text { When I talk this issue with } \\
\text { the family, they consider } \\
\text { sending their child to get } \\
\text { extra courses as a } \\
\text { burden.... }\end{array}$ \\
\hline & $\begin{array}{l}\text { Problems } \\
\text { arising from }\end{array}$ & Social characteristics of gifted children & $\begin{array}{l}\text {...It is highly possible to } \\
\text { confuse these children }\end{array}$ \\
\hline
\end{tabular}




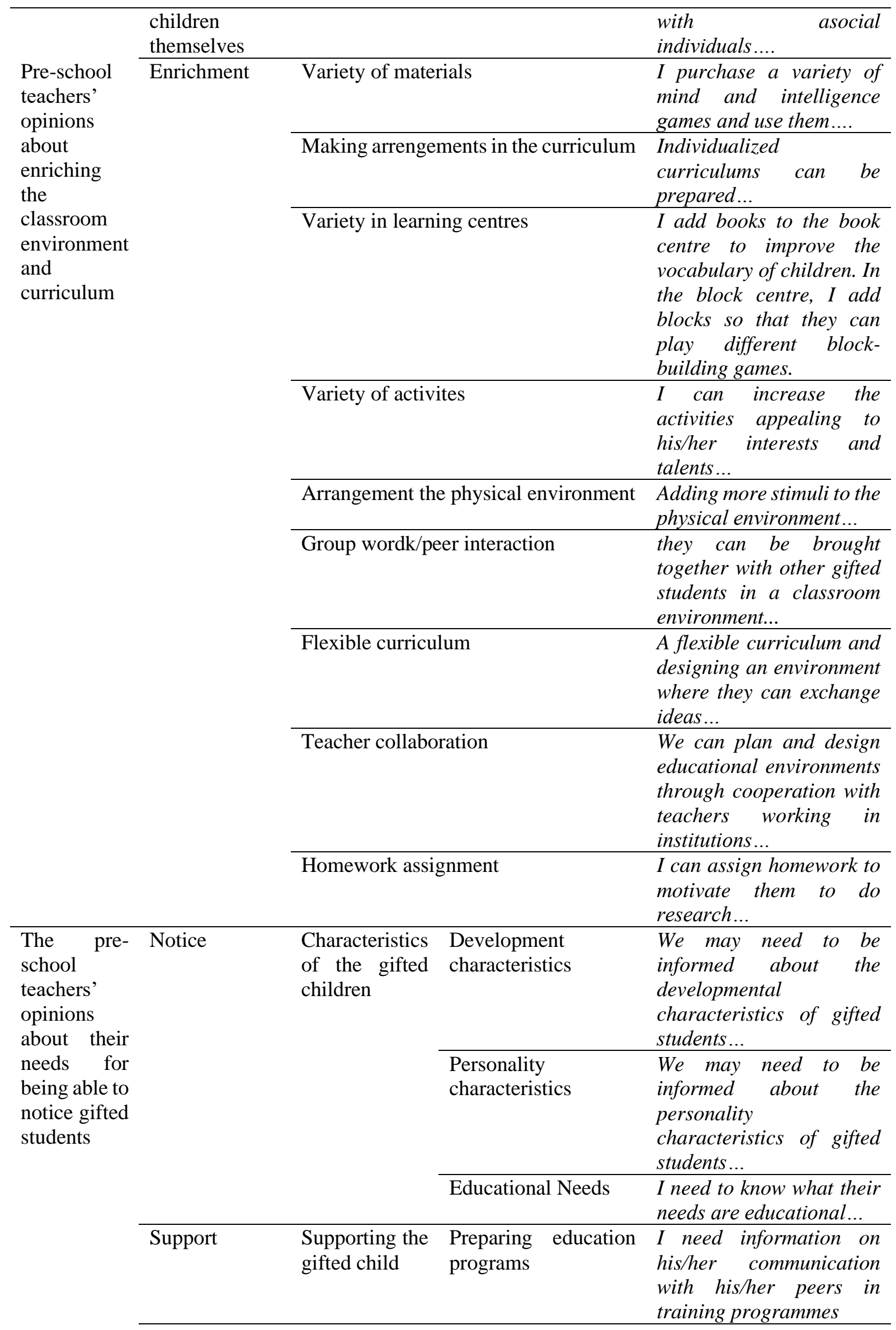




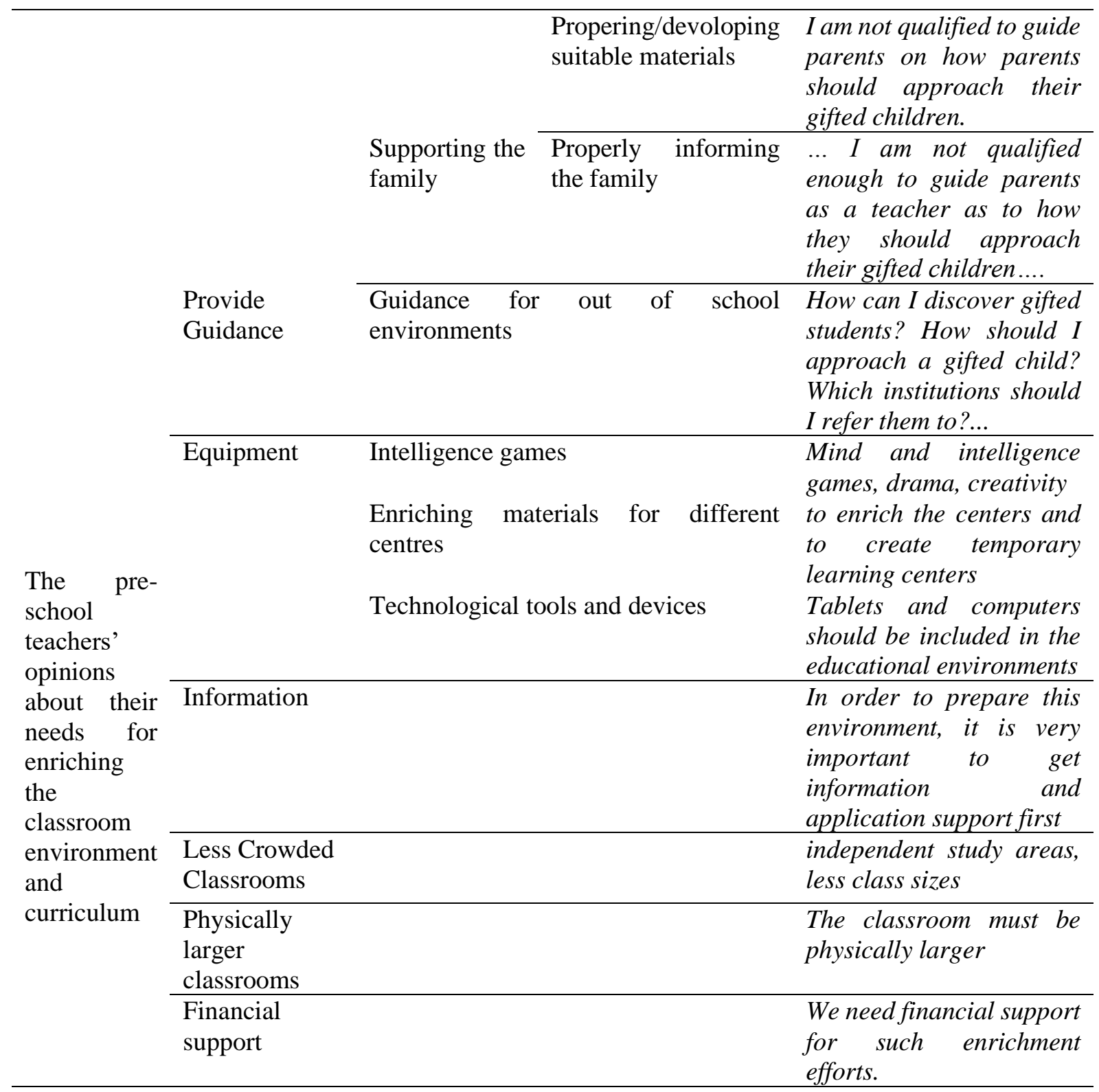

